\title{
Tissue pharmacokinetics of individual macrolides support observed differences in development of bacterial resistance
}

\author{
Shaip Krasniqi ${ }^{1}$, Peter Matzneller ${ }^{1}$, Martina Kinzig ${ }^{2}$, Sven Hüttner², Fritz Sörgel², Markus Müller ${ }^{1}$, Markus Zeitlinger ${ }^{\text {* }}$ \\ From 16th Scientific Symposium of the Austrian Pharmacological Society (APHAR) \\ Vienna, Austria. 25-27 November 2010
}

\section{Background}

Recently, differences in development of bacterial resistance were observed for macrolides with short and long elimination half life. Although one might speculate that this observation is to be explained by prolonged subinhibitory concentrations at the site of bacterial dwelling, the pharmacokinetic (PK) confirmation of this theory is missing. Thus we set out to compare PK of azithromycin and erythromycin in plasma, polymorphonuclear leukocytes (PML) and interstitial space fluid (ISF) of soft tissues.

\section{Methods}

Azithromycin (500 mg o.d.) or erythromycin (500 mg q. i.d.) treatment for three days was randomly administered to 6 healthy volunteers each. Macrolide concentrations were determined on day 1 and day 3 (full PK profile) and on day 5 and 10 (sparse sampling) by tandem mass spectrometry. Concentrations in ISF of muscle and subcutis were determined by microdialysis.

\section{Results}

During active treatment concentrations in plasma and ISF were higher for erythromycin than for azithromycin, whereas in white blood cells they were comparable. Except for azithromycin plasma concentrations and erythromycin PML concentration significant accumulation was observed for all compartments between single dose and day 3. For erythromycin concentrations were not detectable at day 10 for all compartments. In contrast, azithromycin mean concentrations at day 10 were $8 \pm 0$ $\mathrm{ng} / \mathrm{mL}$ in plasma, $9 \pm 3 \mathrm{ng} / \mathrm{mL}$ in muscle, $4 \pm 2 \mathrm{ng} / \mathrm{mL}$ in subcutis and 14,217 $\pm 2,810 \mathrm{ng} / \mathrm{mL}$ in PML.

\section{Conclusions}

$\mathrm{MIC}_{90}$ of azithromycin for typical pathogens of the respiratory tract or soft tissue infections are in the range of $125-4,000 \mathrm{ng} / \mathrm{mL}$. The present study confirms that for azithromycin 7 days after end of treatment sub-inhibitory concentrations are present, thereby strongly supporting the hypothesis of increased development of resistance due to PK reasons. Higher concentrations in PML than in plasma or ISF indicate that slow back-distribution from cells into extracellular space is the underlying PK mechanism.

\section{Author details}

${ }^{1}$ Department of Clinical Pharmacology, Medical University of Vienna, 1090 Vienna, Austria. ${ }^{2}$ Institute for Biomedical and Pharmaceutical Research, 90562 Nürnberg-Heroldsberg, Germany.

Published: 16 November 2010

doi:10.1186/1471-2210-10-S1-A45

Cite this article as: Krasniqi et al:: Tissue pharmacokinetics of individual macrolides support observed differences in development of bacterial resistance. BMC Pharmacology 2010 10(Suppl 1):A45.

\footnotetext{
* Correspondence: markus.zeitlinger@meduniwien.ac.at

'Department of Clinical Pharmacology, Medical University of Vienna, 1090

Vienna, Austria

Full list of author information is available at the end of the article
} 